\title{
HUBUNGAN JOB INSECURITY DAN KOMITMEN ORGANISASI PADA KARYAWAN PT. KX
}

\author{
Viestar Jeffran Markus, \\ Devi Jatmika ${ }^{1}$ \\ Program Studi Psikologi \\ Universitas Bunda Mulia \\ Jl. Lodan Raya No. 2 \\ Jakarta Utara 14430 \\ 'e-mail:dephey@gmail.com
}

\begin{abstract}
An unstable condition of a company causes the need to downsize the organizations structure by doing layoff. This circumstance evokes a feeling of insecurity in the employees, known as job insecurity. The present study's objective was to examine if there is a relationship between job insecurity and organizational commitment in the current employees of PT. KX in Jakarta, while other employees have been laid off. The present study was done by distributing a questionnaire to 89 employees in PT. KX. The study was a correlational research with quantitative method. The sampling technique was criterion sampling. The results showed that there is a significant negative relationship between job insecurity and organizational commitment. Therefore, the conclusion of the present study is that the lower the job insecurity among employees, the higher the organizational commitment towards the company, vice versa.
\end{abstract}

Keywords: job insecurity; organizational commitment; employees.

Abstrak - Kondisi perusahaan yang tidak stabil menyebabkan perusahaan mengambil keputusan untuk melakukan perampingan struktur organisasi, yaitu dengan cara melakukan Pemutusan Hubungan Kerja (PHK). Peristiwa ini menyebabkan rasa tidak aman dalam bekerja yang dirasakan oleh karyawan, atau dikenal dengan job insecurity. Penelitian ini bertujuan untuk mengetahui ada atau tidaknya hubungan antara job insecurity dengan komitmen organisasi pada karyawan PT. KX di Jakarta yang masih bekerja, mengingat sebagian karyawan di perusahaan tersebut mengalami pemutusan hubungan kerja. Penelitian dilakukan dengan menyebarkan kuesioner kepada 89 karyawan di PT. KX. Penelitian ini bersifat korelasional dengan metode kuantitatif. Teknik sampling yang digunakan adalah criterion sampling. Hasil dari penelitian ini menunjukkan terdapat hubungan negatif yang signifikan antara job insecurity dengan komitmen organisasi. Dengan demikian, kesimpulan penelitian ini ialah semakin rendah job insecurity pada karyawan maka semakin tinggi komitmen organisasi pada perusahaan, dan sebaliknya.

Kata kunci: job insecurity; komitmen organisasi; karyawan. 


\section{PENDAHULUAN}

Adanya berbagai proyek pembangunan infrastruktur yang digalang pemerintah saat ini perlu didukung oleh ketersediaan industri dari alat berat. Beberapa kegiatan industri strategis memerlukan alat berat seperti sektor konstruksi, pertambangan, serta kehutanan dan perkebunan. Namun, sejauh ini di Indonesia tidak memiliki perusahaan yang memproduksi alat-alat berat secara langsung, tetapi merupakan Perusahaan Modal Asing yang menyerahkan penjualan kepada perusahaan distributor lokal ("Persaingan Industri Alat Berat Semakin Ketat,“ 2015).

Akan tetapi, hingga tahun 2014, menurut Kementrian Perindustrian Republik Indonesia, penjualan alat berat hanya mencapai angka 8.000 unit (Kementrian Perindustrian Republik Indonesia, 2014). Kondisi yang memprihatinkan ini akibat menurunnya harga batu bara yang berdampak pula pada sektor pertambangan. Walaupun sektor pertanian dan perkebunan juga menggeliat namun belum dapat menggantikan sektor pertambangan (Marketing Research Indonesia, 2015).

Hal tersebut berdampak pada kondisi keuangan serta keberlangsungan hidup perusahaan distributor alat berat di Indonesia. Kondisi keuangan yang cenderung terkoreksi negatif ini juga berpengaruh terhadap kebijakan-kebijakan (policies) yang akan diambil oleh perusahaan guna dapat bertahan ditengah kondisi pasar yang sedang melemah (Purba \& Seniati, 2004). Salah satu kebijakan yang mungkin diambil oleh kebanyakan perusahaan dalam mempertahankan kondisi perusahaan, yaitu dengan cara melakukan perampingan beban biaya (cost efficiency), dan cost efficiency yang dapat dilakukan adalah dengan melakukan perampingan struktur organisasi atau yang sering disebut dengan downsizing (Bosman, Buitendach, \& Rothman, 2005). Downsizing tampaknya menjadi solusi yang dilakukan perusahaan untuk dapat menjaga efektivitas pengeluaran dengan cara mengurangi beban biaya dari gaji para karyawan (reducing cost labour) sehingga perusahaan tetap dapat bertahan ditengahkondisi keuangan yang tidak stabil (Bosman, Buitendach, \& Laba, 2005). Downsizing dapat menyebabkan timbulnya perasaan tidak aman dalam bekerja (job insecurity) pada karyawan yang tetap bertahan (survivor), di mana para karyawan yang bertahan telah mengalami kejadian yang berpotensi hampir membuat mereka kehilangan pekerjaannya, sehingga terbentuk suatu persepsi dan intepretasi yang buruk terhadap lingkungan pekerjaannya (Hartley, dalam Bosman, Buitendach, \& Laba, 2005).

Salah satu perusahaan distributor alat berat yang memiliki fenomena downsizing yaitu PT. KX. PT. KX adalah perusahaan yang pada awalnya berdiri pada tahun 2002 dan secara cepat berkembang luas serta menjelma menjadi salah satu perusahaan distributor alat-alat berat yang terkenal, seperti di bidang industri manufacturing dan pertambangan (mining), serta mencatatkan namanya untuk 
pertama kali di BEI (Bursa Efek Indonesia) pada tanggal 6 Juni 2012 sebagai salah satu perusahaan yang membuka saham untuk publik (Company Profile Magazine). Menurut Kepala Bagian HRD PT. KX, dampak yang dirasakan oleh PT. KX adalah penurunan penjualan alat berat di awal tahun 2015 yang mencapai lebih dari 50\% (komunikasi pribadi, 24 April 2015).

Keadaan finansial perusahaan yang kurang kondusif ini pula yang akhirnya memengaruhi kebijakan-kebijakan perusahaan. Salah satu kebijakan yang dikeluarkan oleh PT. KX adalah Inter Office Memo (IOM) efisiensi. Beberapa poin yang dibahas dari IOM efisiensi tersebut, di antaranya status karyawan kontrak tidak diperpanjang dan tidak ada pengangkatan menjadi karyawan tetap, penutupan kantor cabang yang tidak menguntungkan atau tidak efektif dan pembukaan kantor cabang baru untuk sementara dihentikan, serta pengajuan karyawan baru melalui Form Permintaan Penambahan Karyawan (FPPK) untuk sementara dihentikan dengan jangka waktu yang belum ditentukan.

Dari hasil wawancara singkat yang dilakukan oleh peneliti terhadap tiga karyawan yang berposisi sebagai staf HRD, staf finance, dan staf accounting, mereka menjawab dengan adanya IOM efisiensi tersebut mereka merasa sangat khawatir mengenai keberlangsungan jenjang karier mereka di perusahaan di masa depan. Mereka juga merasa takut jika pengkerucutan jumlah karyawan berdampak pada Pemutusan Hubungan Kerja (PHK) yang dilakukan oleh perusahaan. Selain itu, mereka juga merasa khawatir jika dengan kebijakan IOM efisiensi masih tidak dapat menyelesaikan permasalahan, hal tersebut dapat berdampak pada keberlangsungan kerja mereka di perusahaan (komunikasi pribadi, 24 April 2015). Dampak dari job insecurity ini dapat difokuskan pada dampak psikologis yang bersifat negatif, seperti: munculnya perasaan cemas, depresi, dan tegang (Ferrie, dkk., dalam Wening, 2005). Selain itu, menurut Sverke, Hellgren, dan Näswall (2002) dalam kajian literaturnya, menyatakan bahwa dampak dari job insecurity dapat mengakibatkan berkurangnya komitmen karyawan terhadap perusahaan. Hasil penelitian dari Bosman, Buitendach, dan Laba (2005), yang meneliti mengenai hubungan dari job insecurity, burnout dan komitmen organisasi pada karyawan pada institusi keuangan Gauteng, menunjukkan bahwa job insecurity berasosiasi dalam meningkatkan tingkat kelelahan, rasa sinis karyawan, serta dapat menurunkan komitmen organisasi afektif dan normatif karyawan.

Akan tetapi di sisi lain perusahaan juga masih memerlukan para karyawan untuk tetap menjalankan aktivitas organisasinya. Hal ini diperkuat dengan pernyataan Purba dan Seniati (2004) yang menyatakan bahwa ketika sebuah organisasi melakukan pengurangan jumlah karyawan, organisasi tersebut akan lebih bergantung pada karyawan yang bertahan untuk tetap melakukan pekerjaan demi mempertahankan efektivitas sebuah organisasi. Maka dari itu yang diperlukan oleh perusahaan adalah sebuah komitmen organisasi dari karyawan yang masih bertahan di perusahaan. 
Dengan melihat situasi PT. KX, penelitian ini bertujuan untuk mengetahui apakah ada hubungan antara job insecurity dengan komitmen organisasi pada karyawan-karyawan yang masih bekerja di PT. KX.

\section{Job Insecurity}

Job insecurity menurut De Witte (dalam Bosman, Buitendach, \& Laba, 2005) merupakan perasaan tidak aman yang dirasakan oleh seorang karyawan yang berhubungan dengan persepsi ketakutan akan kehilangan pekerjaannya. Job insecurity juga dapat didefinisikan sebagai suatu situasi yang dialami seorang karyawan di mana ada rasa ketidakberdayaan untuk mempertahankan rasa aman di dalam dirinya dengan situasi kerja yang terjadi. Hal ini disebabkan karena adanya situasi yang mengancam dari situasi pada lingkungan pekerjaannya (Wening, 2005). Penelitian tentang job insecurity sebelumnya menyatakan bahwa karyawan yang bekerja di bawah ikatan kontrak atau bukan karyawan tetap, karyawan yang terlibat dalam penstrukturan ulang struktur organisasi, dan karyawan yang sedang mengalami pengkerucutan (downsizing), akan cenderung mengalami rasa job insecurity (Pearce, dalam Richter, 2011).

Menurut Greenhalgh dan Rosenblatt maupun Ashford dan kawan-kawan. (dalam De Witte, 2005), komponen job insecurity tidak hanya bersifat subjektif individu, tetapi bersifat multidimensional yang terdiri dari tiga komponen. Tiga komponen tersebut yaitu tingkat ancaman yang dirasakan karyawan, arti pekerjaan bagi individu, serta ancaman yang disebabkan oleh peristiwa.

Tingkat ancaman mengenai aspek-aspek pekerjaan, seperti kemungkinan untuk mendapatkan promosi, mempertahankan tingkat upah, atau memperoleh kenaikan upah. Dalam hal arti pekerjaan bagi karyawan, seberapa pentingnya aspek kerja tersebut bagi individu akan mempengaruhi tingkat rasa tidak amannya (insecurity), contohnya pekerjaan tersebut sangat bermakna karena karyawan merupakan tulang punggung bagi keluarga. Dalam hal persepsi ancaman yang disebabkan oleh peristiwa, karyawan merasakan terjadinya peristiwa-peristiwa yang secara negatif memengaruhi keseluruhan kinerja kerjanya, misalnya pernah melihat rekan kerja yang dipecat atau dipindahkan ke kantor cabang yang lain.

Lebih lanjut, Pienaar, De Witte, Hellgren, dan Sverke (2013) berpendapat bahwa job insecurity memiliki dua bentuk, yaitu cognitive job insecurity dan affective job insecurity. Cognitive job insecurity adalah ketakutan akan kehilangan pekerjaan yang dirasakan karyawan berdasarkan pemikiran secara langsung mengenai kemungkinan kehilangan pekerjaan. Hal ini dapat disebabkan karena secara langsung melihat suatu kejadian yang membuat individu berpikir akan adanya kemungkinan dirinya juga dapat kehilangan pekerjaan. Sementara itu, affective job insecurity merupakan bentuk ketakutan akan kehilangan pekerjaan yang diasosiasikan dalam bentuk perasaan takut, khawatir, dan cemas pada 
karyawan itu sendiri. Jadi dapat dikatakan bahwa affective job insecurity memengaruhi faktor psikologis dalam diri karyawan. Studi yang dilakukan Huang dkk. (dalam Pienaar, dkk., 2013) menemukan bahwa affective job insecurity berasosiasi kuat terhadap ketegangan psikologis, sedangkan cognitive job insecurity berhubungan kuat dengan komitmen dan kepuasan bekerja.

\section{Komitmen Organisasi}

Meyer dan Allen (dalam Pramadani, 2012) mendefinisikan komitmen organisasi sebagai indikator sejauh mana seorang karyawan mengalami rasa kesatuan dengan organisasi. Mowday dkk. (dalam Davland, Najafi, Noruzy, Azar, \& Shirkouhuki, 2011) menjelaskan bahwa komitmen organisasi adalah kepercayaan karyawan terhadap nilai-nilai dan tujuan organisasi sehingga karyawan memiliki keinginan untuk tetap menjadi anggota dalam organisasi secara tulus.

Allen dan Meyer (dalam Aamodt, 2013) menjelaskan terdapat tiga bentuk komitmen organisasi, yaitu komitmen afektif, normatif, dan berkelanjutan. Komitmen afektif merupakan keterikatan secara emosional dan keterlibatan karyawan dalam suatu perusahaan. Dalam hal ini individu ingin menetap dalam suatu organisasi karena keinginan dari dirinya sendiri, yakni karena ia merasa adanya keterikatan secara emosional terhadap organisasi. Komitmen berkelanjutan merupakan komitmen individu yang didasari pada pertimbangan mengenai untung dan rugi yang didapatkan oleh karyawan ketika memutuskan untuk menetap ataupun meninggalkan perusahaan. Komitmen normatif merupakan keyakinan individu mengenai tanggung jawab dirinya terhadap perusahaan, sehingga mewajibkan dirinya untuk menetap dalam suatu perusahaan.

\section{METODE}

\section{Partisipan}

Menurut Sugiyono (2014), populasi merupakan wilayah generalisasi yang terdiri atas objek atau subjek yang mempunyai kualitas dan karakteristik tertentu yang ditetapkan oleh peneliti untuk dipelajari dan kemudian ditarik kesimpulannya. Dalam penelitian ini, populasi mencakup keseluruhan dari subjek penelitian, di mana populasinya merupakan seluruh karyawan PT. KX yang berada di kantor pusat (head office), yang berjumlah sekitar 120 orang.

Pengambilan sampel dilakukan di kantor pusat (head office) yang berada di Jakarta. Jumlah sampel dalam penelitian ini adalah 89 subjek, di mana 30 sampel akan berpartisipasi dalam uji coba instrumen dan 59 sampel lainnya untuk uji analisis penelitian. Karakteristik sampel karyawan dengan 
jabatan staf, supervisior, dan manager (golongan 3 ke atas), lama bekerja di atas 6 bulan dan statusnya adalah karyawan tetap.

\section{Desain}

Penelitian ini mengunakan metode penelitian kuantitatif, di mana penelitian kuantitatif adalah suatu penelitian yang menggunakan proses untuk menemukan pengetahuan dengan cara memakai data berupa angka sebagai instrumen untuk menganalisis keterangan mengenai apa yang ingin di ketahui (Creswell, 2010). Jenis penelitian yang digunakan adalah penelitian korelasi, di mana penelitian korelasional adalah penelitian yang suatu hubungan dua variabel atau lebih yang kebetulan munculnya bersama (Sugiyono, 2014).

Kuesioner yang digunakan oleh peneliti untuk variabel job insecurity menggunakan Job Insecurity Quessionaire (JIQ) yang diperkenalkan oleh Pienaar, dkk. (2013). JIQ terdiri dari 8 pertanyaan mengenai job insecurity, yang meliputi pertanyaan mengenai cognitive job insecurity dan affective job insecurity. Pada dimensi cognitive job security memiliki nilai reliabilitas sebesar.8 dan pada dimensi affective job insecurity memiliki nilai reliabilitas sebesar.84 (Pienaar, dkk., 2013).

Dari kuesioner tersebut, peneliti menambahkan 6 butir tambahan untuk masing-masing bentuk job insecurity dengan pertimbangan untuk menghindari banyaknya butir yang gugur saat uji coba. Analisis pernyataan butir-butir yang ditambahkan telah melalui uji pakar, yang kemudian melalui uji coba untuk mengetahui reliabilitas dan validitas dari alat ukur dalam penelitian ini. Kuesioner ini diisi dengan menggunakan skala Likert dengan empat alternatif jawaban yaitu: 1 untuk sangat tidak setuju (STS), 2 untuk tidak setuju (TS), 3 untuk setuju (S), dan 4 untuk sangat setuju (SS). Dalam pernyataan akan disediakan butir pernyataan yang bersifat mendukung pernyataan (favourable) atau tidak mendukung pernyataan (unfavourable).

Kuesioner mengenai komitmen organisasi diadaptasi dari Organizational Commitment Questionnaire (Meyer, Allen, \& Smith, 1993). Terdapat 18 butir pernyataan mengenai gambaran komitmen organisasi yang meliputi tiga bentuk komitmen organisasi, yaitu affective commitment, continuance commitment, dan normative commitment. Nilai reliabilitas Cronbach's alpha untuk affective commitment (.82), continuance commitment (.74), dan normative commitment (.83) (Meyer, dkk., 1993). Kuesioner ini diisi dengan menggunakan skala Likert dengan empat alternatif jawaban yaitu: 1 untuk sangat tidak setuju (STS), 2 untuk tidak setuju (TS), 3 untuk setuju (S) dan 4 untuk sangat setuju (SS). 


\section{Prosedur}

Persiapan yang dilakukan oleh peneliti sebelum melaksanakan penelitian adalah dengan merancang dan menyusun penelitian. Peneliti mengumpulkan studi pustaka berupa buku dan jurnal penelitian serta literatur penelitian yang berhubungan dengan judul penelitian yang akan dilakukan. Setelah itu, untuk mengumpulkan fenomena yang terjadi di lapangan, peneliti mengumpulkan datadata statistik serta melakukan wawancara dengan beberapa karyawan perusahaan PT. KX untuk mengumpulkan informasi. Kemudian peneliti menyusun instrumen penelitian yang merupakan adaptasi dari Job Insecurity Questinnaire (JIQ; Pienaar, dan kawan-kawan., 2013) dan Organizational Commitment Questionnaire (Meyer, dkk., 1993) ke dalam bahasa Indonesia dan dilakukan beberapa revisi penggunaan kata, agar lebih memudahkan subjek penelitian untuk mengerti maksud dari pertanyaan tersebut. Penyebaran kuesioner dilakukan pada divisi back office seperti HRD, Finance, Accounting, Procurement, IT, dan Customer Service Officer (CSO), lalu setelah 1 bulan, kuesioner yang telah diisi dikembalikan oleh pihak perusahaan dikarenakan ada beberapa divisi yang memerlukan waktu mengisi lebih lama karena keterbatasan waktu seperti divisi Marketing, Internal Audit, dan Pricing \& Inventory. Peneliti melakukan uji coba dan penyebaran kuesioner terhadap 30 orang karyawan untuk melihat tingkat validitas dan reliabilitas alat ukur dalam penelitian serta 59 karyawan lainnya untuk menguji hipotesis penelitian.

\section{Teknik Analisis}

Teknik analisis data yang digunakan dalam penelitian ini adalah teknik korelasi Pearson. Korelasi Pearson adalah teknik statistik yang dapat mengukur hubungan antara dua variabel yang berdistribusi normal. Pada teknik korelasi ini dapat menyatakan ada atau tidak hubungan antara variabel $\mathrm{X}$ dan variabel Y (Nisfianoor, 2009).

\section{ANALISIS DAN HASIL}

\section{Uji Validitas dan Reliabilitas}

Dari hasil uji coba, didapatkan bahwa terdapat 7 dari 29 butir yang gugur dari JIQ dengan rentang validitas.142-.759 dan diperoleh hasil reliabilitas Cronbach's alpha sebesar.862. Sementara itu, untuk Organizational Commitment Questionnaire, terdapat satu dari 18 butir yang gugur dengan rentang validitas.351 -.776 dengan nilai reliabilitas Cronbach's alpha sebesar.896. 


\section{Karakteristik Demografis Partisipan}

Gambaran demografis partisipan penelitian dapat dilihat pada tabel sebagai berikut.

Tabel 1. Gambaran Demografis Partisipan

\begin{tabular}{llll}
\hline Gamabaran Demografis & Keterangan & Frekuensi & Persentase \\
\hline Jenis Kelamin & Laki-laki & 39 & 66 \\
& Perempuan & 13 & 23 \\
& Tidak diisi & 7 & 11 \\
\hline \multirow{3}{*}{ Lama Bekerja } & $<2$ tahun & 18 & 31 \\
& $2-5$ tahun & 18 & 31 \\
& $5-10$ tahun & 11 & 18 \\
& $>10$ tahun & 3 & 6 \\
& Tidak diisi & 9 & 14 \\
\hline Usia Karyawan & $21-25$ tahun & 11 & 18 \\
& $25-30$ tahun & 13 & 22 \\
& $31-35$ tahun & 17 & 29 \\
& $36-40$ tahun & 6 & 11 \\
& $>40$ tahun & 5 & 8 \\
& Tidak diisi & 7 & 13 \\
\hline \multirow{3}{*}{ Jabatan } & Staff & 39 & 66 \\
& Section Head & 9 & 9 \\
& Manager & 2 & 4 \\
& Tidak diisi & 9 & 15 \\
\hline
\end{tabular}

\section{Hasil Uji Normalitas}

Berdasarkan hasil uji normalitas menggunakan teknik Kolmogorov-Smirnov, diketahui pada variabel job insecurity maupun komitmen organisasi, data yang diperoleh berdistribusi normal (dengan nilai $p$ berturut-turut.498 dan.357).

\section{Hasil Uji Korelasi}

Hasil uji korelasi menunjukkan adanya korelasi negatif yang signifikan $(r=-.629, p=.000)$ antara job insecurity dengan komitmen organisasi pada karyawan PT. KX. Hal ini berarti, semakin tinggi tingkat job insecurity pada karyawan PT. KX, maka akan semakin rendah komitmen organisasinya, begitu pula sebaliknya.

\section{Analisis Data Tambahan}

Peneliti menggunakan kuesioner pertanyaan terbuka untuk mengetahui apakah karyawan merasa aman saat bekerja, serta untuk mengetahui makna rasa aman bagi karyawan dan makna perusahaan bagi karyawan. 
Tabel 2. Pernyaataan Rasa Aman atau Tidak Aman Bekerja di PT. "KX” beserta Alasannya

\begin{tabular}{ll}
\hline Respons & Jumlah Subyek \\
\hline Karyawan yang menyatakan Aman & 34 \\
Perusahaan masih membutuhkan jasa karyawan & \\
(Lack of Human Resources) & 12 \\
Perusahaan masih memenuhi hak-hak untuk karyawan & 22 \\
Karyawan yang menyatakan Tidak Aman & 16 \\
Stabilitas perusahaan yang rendah & 13 \\
Pressure tinggi dari peraturan perusahaan & 1 \\
Ketidakpastian akan masa depan & 2 \\
Tidak Menjawab & 9 \\
\hline Total & 59 \\
\hline
\end{tabular}

Tabel 3. Makna Rasa Aman bagi Karyawan

\begin{tabular}{lll}
\hline Makna Rasa Aman Bagi Karyawan & Jumlah Subyek & Persentase \\
\hline Kerja dengan porsi normal & 6 & $12 \%$ \\
Tunjangan karyawan & 27 & $54 \%$ \\
Hubungan atasan dengan bawahan & 4 & $8 \%$ \\
Perusahaan bangkit dari keterpurukan & 5 & $10 \%$ \\
Jenjang karir yang jelas & 4 & $8 \%$ \\
Kontribusi pribadi untuk perusahaan & 4 & $8 \%$ \\
\hline Total & 50 & $100 \%$ \\
\hline
\end{tabular}

Tabel 4. Makna Perusahaan Bagi Karyawan

\begin{tabular}{lll}
\hline Makna Perusahaan Bagi Karyawan & Jumlah Subyek & Persentase \\
\hline Tempat mencari nafkah & 29 & $58 \%$ \\
Perusahaan sebagai keluarga / rumah kedua & 14 & $28 \%$ \\
Tempat berkarir dan pengembangan diri & 7 & $14 \%$ \\
\hline Total & 50 & $100 \%$ \\
\hline
\end{tabular}

\section{DISKUSI}

Dari hasil penelitian yang dilakukan dengan menggunakan korelasi Pearson, didapatkan bahwa ada hubungan antara job insecurity dan komitmen organisasi pada karyawan di PT. KX. De Witte (2005) menjelaskan bahwa komponen job insecurity merupakan komponen yang bersifat persepsi subjektif dari hasil persepsi ketidakamanan pada masa depan. Variasi dari persepsi individu, ada yang merasa lebih pesimis adapula yang tidak, ada yang menyikapi lebih realistis adapula yang tidak, sehingga respons dari peristiwa kehilangan pekerjaan juga bervariasi.

Persepsi subjektif karyawan terhadap job insecurity yang dirasakan merupakan interaksi dari tiga komponen yaitu: (1) tingkat ancaman yang dirasakan seperti kemungkinan promosi atau 
mempertahankan upah; (2) arti pekerjaan itu sendiri; (3) tingkat ancaman yang disebabkan oleh peristiwa (Ashford, dalam De Witte, 2005). Selain itu, affective commitment yang cenderung tinggi dan kemudian diikuti dengan normative commitment dan continuance commitment pada karyawan PT. KX mengartikan bahwa karyawan memiliki ikatan emosional dan tetap tinggal di perusahaan karena mereka menginginkannya. Penelitan sebelumnya yang dilakukan oleh Furaker dan Berglund (2014) menyatakan bahwa pemutusan hubungan kerja yang semakin meningkat dan kecemasan kehilangan pekerjaan justru meningkatkan komitmen kerja. Hal ini mengindikasikan individu menjadi semakin menghargai pekerjaan dan tempat kerja mereka.

Dari hasil pertanyaan terbuka juga didapatkan bahwa karyawan memiliki tingkat job insecurity rendah karena mereka berpendapat bahwa perusahaan masih memenuhi hak-hak mereka dan juga masih membutuhkan mereka sebagai karyawan dan ini direspon pula dengan makna rasa aman bagi karyawan berupa tunjangan yang didapatkan serta makna perusahaan sendiri bagi karyawan adalah sebagai tempat untuk mencari nafkah.

Hasil dalam penelitian ini masih perlu dikembangkan karena adanya keterbatasan penelitian karena membutuhkan waktu bagi karyawan untuk mengisi kuesioner dan tidak semua karyawan masuk setiap harinya, maka sebagian pengambilan data diambil dengan menitipkan kepada pihak HR. Hal ini dapat memungkinkan terjadinya bias social desirability yaitu karyawan memberikan jawaban agar terlihat baik atau menuruti keinginan normatif.

\section{SIMPULAN DAN SARAN}

\section{Simpulan}

Penelitian ini menunjukkan bahwa job insecurity berkorelasi negatif dengan komitmen kerja karyawan PT. KX. Job insecurity yang dirasakan karyawan cenderung rendah, sedangkan komitmen kerjanya cenderung tinggi. Maka dari itu, dapat disimpulkan bahwa karyawan PT. KX yang masih bekerja secara psikologis masih merasakan kenyamanan dan kesediaan untuk bekerja di perusahaan tersebut. Hal ini dapat dikarenakan kepercayaan karyawan terhadap perusahaan dan perlakuan perusahaan yang konsisten dalam memenuhi hak-hak karyawan.

\section{Saran Teoretis}

Bagi penelitian selanjutnya, hendaknya dapat menggunakan subjek penelitian dengan populasi yang lebih besar karena dalam penelitian ini populasi yang diperoleh terbatas mengingat saat penelitian ini 
dilakukan seiring waktu terdapat karyawan-karyawan yang diberhentikan di PT. KX. Penelitian selanjutnya juga dapat menambahkan data kualitatif untuk memperdalam apa yang dirasakan oleh karyawan yang menghadapi kondisi perusahan yang tidak stabil dan sumber komitmen yang dimiliki. Selain itu, untuk penelitian selanjutnya, dapat mengembangkan penelitian job insecurity variabel-variabel lainnya seperti kepercayaan, loyalitas karyawan, keterlibatan kerja, organizational citizenship behavior pada karyawan.

\section{Saran Praktis}

Saran bagi karyawan di PT. KX adalah tetap melakukan pekerjaan dengan penuh tanggung jawab. Bagi perusahan-perusahaan lainnyayang menghadapi situasi krisis serupa dengan PT. KX disarankan dapat memberikan perhatian dan pendekatan secara personal dari pihak manajemen mengenai situasi perusahaan. Pada hasil penelitian terlihat bahwa karyawan PT. KX yang masih bekerja memiliki komitmen yang tinggi, hal ini merupakan hal yang positif karena karyawan- karyawan masih berharap bahwa perusahan dapat bangkit kembali dan pendekatan personal dan perhatian terhadap hak-hak karyawan selama mereka bekerja terpenuhi dengan baik.

\section{REFERENSI}

Aamodt, M. G. (2013). Industrial/Organizational psychology: An applied approach (7th ed). Belmont, CA: Cengage Learning.

Bosman, J., Buitendach, J, H., \& Laba, K. (2005). Job insecurity, burnout and work organizational commitment among employees of financial institution in Gauteng. Journal of Industrial Psychology, 31(4), 32-40.

Bosman, J., Buitendach, J, H, \& Rothman, S. (2005). Job insecurity, burnout and work engagement: The impact of positive and negative affectivity. Journal of Industrial Psychology, 31(4), 48-56.

Creswell, J. W. (2010). Research design: Qualitative, quantitative and mixed methods approache (3rd ed.). California, CA: Sage.

Davland, M. R., Najafi, S., Noruzy, A., Azar, H. K., \& Shirkouhuki, S. N. (2011). Investigating the relationship between organizational justice, psychological empowerment, job satisfaction, organizational commitment and organizational citizenship behavior: An empirical model. Journal of Business Management, 5(13), 5241-5248.

De Witte, H. (2005). Job insecurity: review of international literature on definitions, prevalence, antecendents and consequences. Journal of Industrial Psychology, 31(4), 1-6. 
Furaker, B., \& Berglund, T. (2014). Job insecurity and organizational commitment. Ditemu kembali dari https://dialnet.unirioja.es/descarga/articulo/4995510.pdf

Kementrian Perindustrian Republik Indonesia. (2014). Produksi alat berat "tergilas" penurunan sektor tambang. Ditemu kembali dari http://www.kemenperin.go.id/artikel/4806/Produksi-Alat-Berat

Marketing Research Indonesia. (2015). Semakin berat perkembangan industri alat berat. Ditemu kembali dari http://www.mri-research-ind.com/berita-329-semakin-berat-perkembangan-industrialat-berat.html.

Meyer, J. P., Allen, N. J., \& Smith, C. A. (1993). Commitment to organizations and occupations: Extension and test of a three-component conceptualization. Journal of Applied Psychology, 78(4), 538-551.

Nisfiannoor, M. (2009). Pendekatan Statistika Modern untuk Ilmu Sosial. Jakarta, Indonesia: Salemba Humanika.

Persaingan Industri Alat Berat Semakin Ketat. (2015). Steel Indonesia News. Ditemu kembali dari http://steelindonesianews.com/detail.asp?id=1685

Pienaar, J., De Witte, H., Hellgren, J., \& Sverke, M. (2013). The cognitive/affective distinction of job insecurity: Validation and differential relations. Southern African Business Review, 17(2), 1-22.

Pramadani, A. B. (2012). Hubungan antara komitmen organisasi dengan kesiapan untuk berubah pada karyawan Divisi Enterprise Service (DES) Telkom Ketintang Surabaya. Jurnal Psikologi Industri dan Organisasi, 1(2), 102-109.

Purba, D, E., \& Seniati, A, N. (2004). Pengaruh kepribadian dan komitmen organisasi terhadap organizational citizenship behavior. Makara Sosial Humaniora, 8(3), 105-111.

Richter, A. (2011). Job insecurity and its consequences. Department of Psychology, Stockholm University. Ditemu kembali dari https://www.researchgate.net/publication/265674531_Job_ Insecurity_and_Its_Consequences_Investigating_Moderators_Mediators_and_Gender.

Sugiyono. (2014). Metode Penelitian Kuantitatif, Kualitatif dan R\&D. Bandung, Indonesia: Alfabeta.

Sverke, M., Hellgren, J., \& Näswall, K. (2002). No security: A meta analysis and review of job insecurity and its consequences. Journal of Occupational Health Psychology, 7(3), 242-264.

Wening, N. (2005). Pengaruh ketidakamanan kerja (job insecurity) sebagai dampak restrukturisasi terhadap kepuasan kerja, komitmen organisasi dan intensi keluar. Kinerja, 9(2), 135-147. 